\title{
Ortho-substituted PCB 153: effects in CHO-K1 cells
}

\author{
Marina Miletić ${ }^{1}$, Teuta Murati ${ }^{1}$, Branimir Šmić $^{1}$, Nina Bilandžić ${ }^{2}$, Anamaria Brozovićc \\ and Ivana Kmetič ${ }^{1}$ \\ ${ }^{1}$ University of Zagreb Faculty of Food Technology and Biotechnology, Laboratory for Toxicology, Zagreb, Croatia \\ ${ }^{2}$ Croatian Veterinary Institute, Department of Veterinary Public Health, Laboratory for Residue Control, Zagreb, Croatia \\ ${ }^{3}$ Ruđer Bošković Institute, Division of Molecular Biology, Laboratory for Cell Biology and Signalling, Zagreb, Croatia
}

[Received in September 2021; Similarity Check in September 2021; Accepted in November 2021]

\begin{abstract}
Non-planar di-ortho-substituted PCB 153 (2,2',4,4',5,5'-hexachlorobiphenyl), one of the most abundant PCB congeners in the environment and in biological and human tissues, has been identified as potential endocrine disruptor affecting the reproductive and endocrine systems in rodents, wildlife, and humans. The aim of this study was to gain a deeper insight into its mode/mechanism of action in Chinese hamster ovary K1 cells $(\mathrm{CHO}-\mathrm{K} 1)$. PCB $153(10-100 \mu \mathrm{mol} / \mathrm{L})$ inhibited CHO-K1 cell proliferation, which was confirmed with four bioassays (Trypan Blue, Neutral Red, Kenacid Blue, and MTT), of which the MTT assay proved the most sensitive. PCB 153 also induced ROS formation in a dose-dependent manner. Apoptosis was seen after $6 \mathrm{~h}$ of exposure to PCB 153 doses $\geq 50 \mu \mathrm{mol} / \mathrm{L}$, while prolonged exposure resulted in the activation of the necrotic pathway. PCB 153-induced disturbances in normal cell cycle progression were time-dependent, with the most significant effects occurring after $72 \mathrm{~h}$.
\end{abstract}

KEY WORDS: cell cycle progression; cell death; cytotoxicity; polychlorinated biphenyls; ROS

Polychlorinated biphenyls (PCBs) are a class of persistent organic chemicals whose slow biodegradation in the environment and high lipophilicity allow them to bioaccumulate and reach high concentrations in food, mainly fish, meat, and dairy products (1). Although PCB levels are constantly decreasing in the environment (2), the risk is still present in Croatia due to leakage from power and industrial plants destroyed in war operations between 1991 and 1995 (3) and inadequate landfill disposal of transformers and capacitors.

One of the most persistent among them is the di-orthosubstituted non-planar congener PCB 153 (2,2',4,4',5,5'-hexachlorobiphenyl) (4). Its half-life in the environment is 110 years (5) and in the body 12.4 years (6). For this reason, it is included in the list of six indicator PCBs recommended for monitoring by the Stockholm Convention on Persistent Organic Pollutants (POPs) (7). Furthermore, it is one of the most abundant PCB congeners in the edible tissue of the blue mussels (Mytilus galloprovincialis) collected along the Croatian Adriatic coast (8), in the adipose tissue of red (Cervus elaphus L.) and fallow (Dama dama L.) deer collected in inland and coastal Croatia (9), and in human milk samples collected from lactating mothers from the Croatian capital Zagreb, north Adriatic island of Krk, and coastal town of Zadar (10, 11). Serum PCB concentrations can reach approximately
$3 \mu \mathrm{mol} / \mathrm{L}$ in exposed humans, but PCB levels in extracellular space are not known (12).

PCBs are known to disrupt the endocrine, immune, nervous, and reproductive systems $(13,14)$, but because most such studies have been carried out with Aroclor mixtures, little is known about the exact mechanisms of action of individual PCBs, particularly with respect to the ovaries. Sechman et al. (15) have reported that PCB 153 disrupts follicular steroidogenesis, oestrogen receptor expression, and recruitment of small yellow follicles into the preovulatory hierarchy. Wojtowicz et al. (16) reported various disruptive effects on oestradiol, progesterone, and testosterone secretion from ovarian cells in vitro, and Gregoraszczuk et al. (17) reported decreased testosterone secretion from large preovulatory porcine follicles, accompanied by the inhibition of caspase- 3 activity and apoptotic body formation. Bonefeld-Jørgensen et al. (18) reported inhibited ligand-mediated oestrogen receptor activities in the mammary epithelial cell line MCF-7.

In our previous study we reported the molecular mechanisms of one of the most toxic PCB congeners dioxin-like PCB 77 in Chinese hamster ovary K1 cells (13). The aim of this study was to expand research to PCB 153, as it differs from PCB 77 in the degree of chlorination, planarity, and activity. 


\section{MATERIALS AND METHODS}

\section{Materials}

The Chinese hamster ovary cell line (CHO-K1) was purchased from the American Type Culture Collection (ATCC, Manassas, VA, USA). Dulbecco's MEM F-12 (DMEM F-12), heat inactivated foetal bovine serum (FBS), and trypsin/EDTA solution (0.25\% trypsin with EDTA $4 \mathrm{Na}$ ) were supplied by GIBCO (Paisley, UK). PCB 153 (2,2',4,4',5,5'-hexachlorobiphenyl, CAS 35065-27-1), Trypan Blue dye (CAS 72-57-1), MTT (3-(4,5-dimethyl2-thiazolyl)-2,5-diphenyl-2 h-tetrazolium bromide, CAS 298-93-1), and propidium iodide (PI, CAS 25535-16-4) were obtained from Sigma-Aldrich (St. Louis, MO, USA). Coomassie brilliant blue R-250 (CAS 6104-59-2) was purchased from LKB (Bromma, Sweden). Neutral Red dye (CAS 553-24-2) and Muse ${ }^{\mathrm{TM}}$ Annexin V \& Dead Cell Kit (cat \#MCH100105) were supplied by Merck (Billerica, MA, USA). The 2',7'-dichlorofluorescin diacetate (DCFDA) Cellular ROS Detection Assay Kit (cat \#ab113851) was obtained from Abcam (Cambridge, UK). DMSO (CAS 67-68-5) and ethanol (CAS 64-17-5) were purchased from Kemika (Zagreb, Croatia).

\section{Cell line, culture conditions, and cell viability analysis}

Adherent, epithelial-like CHO-K1 cells were grown in DMEM F-12 supplemented with $10 \%(\mathrm{v} / \mathrm{v}) \mathrm{FBS}$ in a $5 \%$ $\mathrm{CO}_{2}$ humidified environment at $37^{\circ} \mathrm{C}$. Antibiotics were not used during the study. In order to perform cell viability analysis, exponentially growing cells were trypsinised and seeded in 6-well plates at an initial concentration of $2 \times 10^{4}$ cells $/ \mathrm{mL}$ in $2 \mathrm{~mL}$ of culture medium. After an overnight incubation, cells were treated with $10 \mu \mathrm{L} / \mathrm{mL}$ of different PCB dilutions in DMSO to obtain the desired final concentration $(10,25,50,75$, or $100 \mu \mathrm{mol} / \mathrm{L})$ in culture medium for $6,24,48$, and $72 \mathrm{~h}$. Samples treated with $10 \mu \mathrm{L} /$ mL DMSO were used as controls.

Viability and proliferation endpoints were quantified with a battery of in vitro tests covering general cytotoxicity. The toxicological evaluation of PCB 153 followed a stepwise approach suggested by Fernández Freire et al. (19) and previously reported for PCB 77 (13). To collect as much information about PCB 153 cytotoxicity we used four assays with different endpoints. The Trypan Blue (TB) exclusion assay distinguishes live from dead cells by labelling only the cells with impaired membranes. The MTT reduction assay (gold standard for determining cell viability and proliferation) measures cellular metabolic activity as an effect of dehydrogenase enzymes in the mitochondria of live cells. The Neutral Red (NR) uptake assay measures the ability of viable cells to uptake weak cationic dye in lysosomes. The last, Kenacid Blue (KB) assay, measures the change in total cell protein content.
The CHO-K1 cells were exposed to $10-100 \mu \mathrm{mol} / \mathrm{L}$ PCB 153, and cell proliferation and viability were determined after $6,24,48$, and $72 \mathrm{~h}$ of treatment. The assays were conducted as described earlier (20) with minor modifications. For each assay and each time point at least two experiments were performed, and within a single experiment each PCB 153 concentration was tested in triplicate.

\section{Cytofluorimetric analysis of apoptosis}

Percentages of live, apoptotic, and dead cells after treatment with PCB 153 were determined using the Muse ${ }^{\mathrm{TM}}$ Annexin V \& Dead Cell Kit and the Muse ${ }^{\mathrm{TM}}$ Cell Analyzer (Merck) following the manufacturer's protocol. Briefly, after 6 and $48 \mathrm{~h}$ of exposure to PCB 153 (10, 50, and $100 \mu \mathrm{mol} / \mathrm{L})$, both floating and adherent CHO-K1 cells (plated at a density of $2 \times 10^{4}$ cells $/ \mathrm{mL}$ ) were collected, centrifuged at $600 \mathrm{~g} / \mathrm{min}$, and suspended in cell culture medium. Cell suspension aliquots $(100 \mu \mathrm{L})$ were added to Muse $^{\mathrm{TM}}$ Annexin V \& Dead Cell Reagent $(100 \mu \mathrm{L})$ and incubated at room temperature in the dark and analysed after 20 min with the Muse ${ }^{\mathrm{TM}}$ Cell Analyzer. For indicated time points each PCB 153 concentration was tested in triplicate.

\section{Cell cycle analysis}

Cellular DNA content and cell cycle progression upon PCB $153(50 \mu \mathrm{mol} / \mathrm{L})$ treatment were determined by flow cytometry using propidium iodide (PI). The cells were collected by centrifugation, washed with PBS, centrifuged again, and fixed in ice-cold $70 \%$ ethanol at indicated time points (after $6,16,24,48$, and $72 \mathrm{~h}$ of PCB treatment). The samples were stored at $-20{ }^{\circ} \mathrm{C}$. On the day of analysis, cell samples were centrifuged and washed twice in PBS, resuspended in a solution of RNAse $(0.1 \mathrm{mg} / \mathrm{mL})$ and PI $(0.02 \mathrm{mg} / \mathrm{mL})$ in PBS, and incubated in the dark at room temperature for at least $30 \mathrm{~min}$. Cytometry was performed on a BD FACSort flow cytometer using CellQuest ${ }^{\mathrm{TM}}$, and data analysed with the ModFit LT ${ }^{\mathrm{TM}}$ software (Topsham, ME, USA).

\section{Reactive oxygen species determination}

Reactive oxygen species (ROS) formation was determined spectrofluorimetrically with the DCFDA Cellular ROS Detection Assay Kit following the manufacturer's protocol. CHO-K1 cells were seeded in 96-well black plates $\left(1 \times 10^{5}\right.$ cells $/ \mathrm{mL} ; 100 \mu \mathrm{L}$ per well). After overnight incubation, cells were stained with DCFDA for $45 \mathrm{~min}$, then washed with buffer, and exposed to 10$100 \mu \mathrm{mol} / \mathrm{L}$ PCB 153 at $37^{\circ} \mathrm{C}$ for $3 \mathrm{~h}$. Fluorescence was measured with a Varian Cary Eclipse Spectrofluorimeter (Palo Alto, USA) at excitation / emission wavelengths of $485 \mathrm{~nm} / 535 \mathrm{~nm}$. Data are reported as percentages of control (cells treated with $10 \mu \mathrm{L} / \mathrm{mL}$ DMSO) $\pm \operatorname{SEM}(\mathrm{n}=5)$. 


\section{Statistical analysis}

A two-tailed Student's $t$-test was used to determine statistically significant $(\mathrm{p}<0.05)$ differences from control. The results are reported as means \pm SEM.

\section{RESULTS AND DISCUSSION}

\section{Comparison of PCB 153 cytotoxicity established with four in vitro tests}

Figure $1(\mathrm{~A}-\mathrm{D})$ summarises the results of four in vitro bioassays used to assess PCB 153 toxicity. All assays showed quite a similar dose-response pattern, save for a slight inconsistency observed with the KB assay. The MTT assay detected the first significant cytotoxic events as early as after $6 \mathrm{~h}$ and the TB exclusion assay after $24 \mathrm{~h}$ of exposure to $25 \mu \mathrm{mol} / \mathrm{L}$ PCB 153 compared to control $(\mathrm{p}<0.05)$. The observed early sensitivity of the MTT assay might be related to mitochondrial dysfunction induced by PCB (e.g. reduced cellular ATP production and mitochondrial membrane potential, decreased oxidative phosphorylation and aerobic glycolysis), as suggested by other studies (21).

The fact that the NR and TB assays showed almost complete loss of cell viability at $48 \mathrm{~h}$ and $72 \mathrm{~h}$ of exposure to the highest PCB 153 dose $(100 \mu \mathrm{mol} / \mathrm{L})$ suggests that the main cellular targets of its cytotoxicity are the cell membrane and lysosomes (especially at prolonged incubation). This has been confirmed by lower $\mathrm{IC}_{50}$ values obtained with these two bioassays than with the MTT and
$\mathrm{KB}$ assays (Table 1). Variations in $\mathrm{IC}_{50}$ values between the four assays suggest that combining multiple assays with different endpoints (such as membrane integrity, lysosomal activity, total cellular protein content, and mitochondrial function) can provide valuable information about possible mechanisms of action of the tested compound. Compared to the $\mathrm{IC}_{50}$ values obtained for planar dioxin-like PCB 77 from our previous study (13), non-planar di-orthosubstituted PCB 153 in this study (Table 1) showed a much weaker toxic effect on ovarian cells, especially after prolonged exposure.

\section{Cell death induced by PCB 153}

Figure 2 shows the distribution of apoptotic cells in the first $6 \mathrm{~h}$ of exposure to PCB 153, established with the cytofluorimetric analysis using annexin $\mathrm{V}$ and 7-AAD as markers. Significant differences from control started with doses $\geq 50 \mu \mathrm{mol} / \mathrm{L}$. At $50 \mu \mathrm{mol} / \mathrm{L}$ significantly higher was the fraction of cells in early apoptosis $(p<0.025)$, while at $100 \mu \mathrm{mol} / \mathrm{L}$ both early and late apoptotic cell fractions significantly increased ( $\mathrm{p}<0.01$ and $\mathrm{p}<0.001$, respectively). After $48 \mathrm{~h}$, apoptosis gave way to necrosis (Figure 3 ). The observed decrease in the number of viable cells was concentration-dependent. Our results in ovarian cells are consistent with related literature data (22-25). Considering the consistent apoptosis induction in cells of reproductive tissues, the inhibitory effect of PCBs should also be investigated on cancer cell lines. To date, there are many papers addressing the carcinogenicity of $\mathrm{PCBs}$, but data
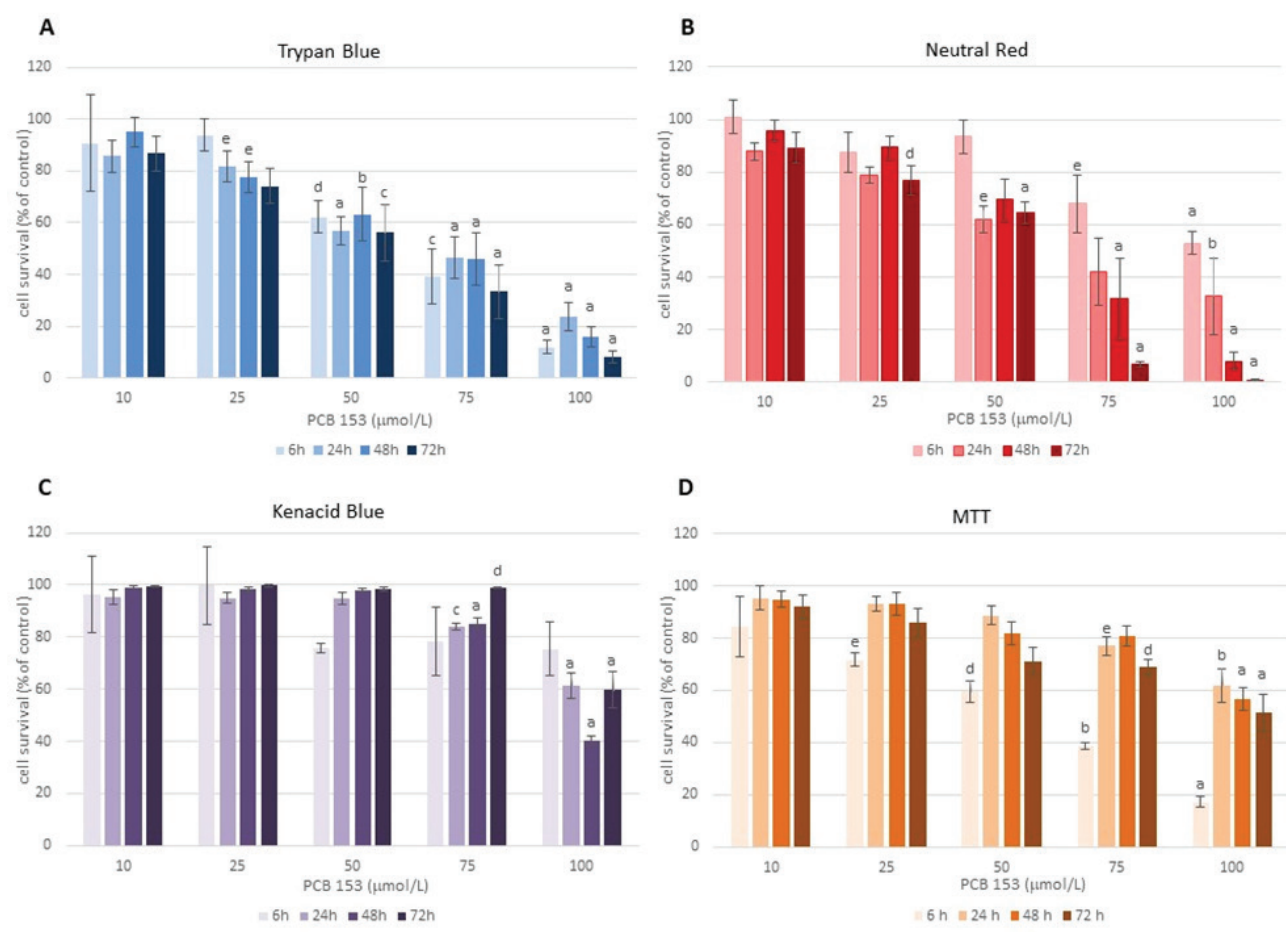

Figure 1 The effects of 10-100 $\mu \mathrm{mol} / \mathrm{L}$ PCB 153 on the viability and proliferation of CHO-K1 cells after 6, 24, 48, and $72 \mathrm{~h}$ of exposure determined with the Trypan Blue (A), Neutral Red (B), Kenacid Blue (C), and MTT assays (D). Data are presented as mean percentages of control ( \pm SEM). Statistical significance $v s$ control: ${ }^{a} \mathrm{p}<0.001 ;{ }^{b} \mathrm{p}<0.005 ;{ }^{\mathrm{c}} \mathrm{p}<0.01 ;{ }^{\mathrm{d}} \mathrm{p}<0.025 ;{ }^{\mathrm{e}} \mathrm{p}<0.05$ 
A
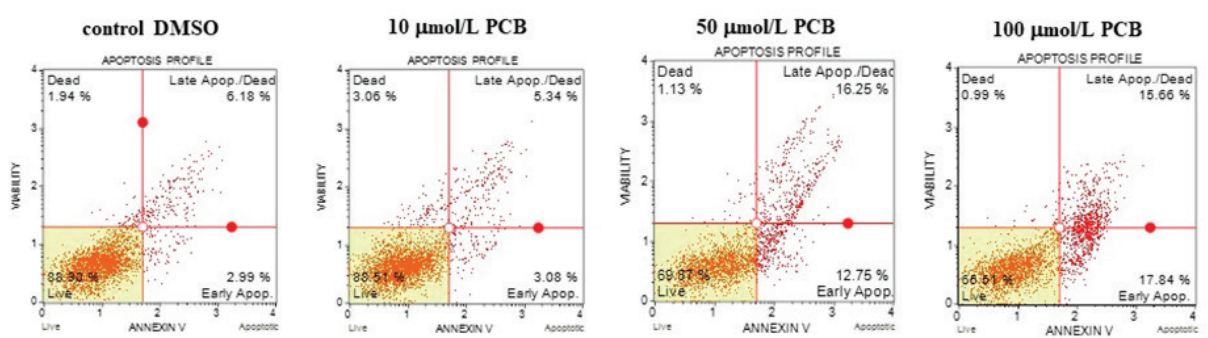

C
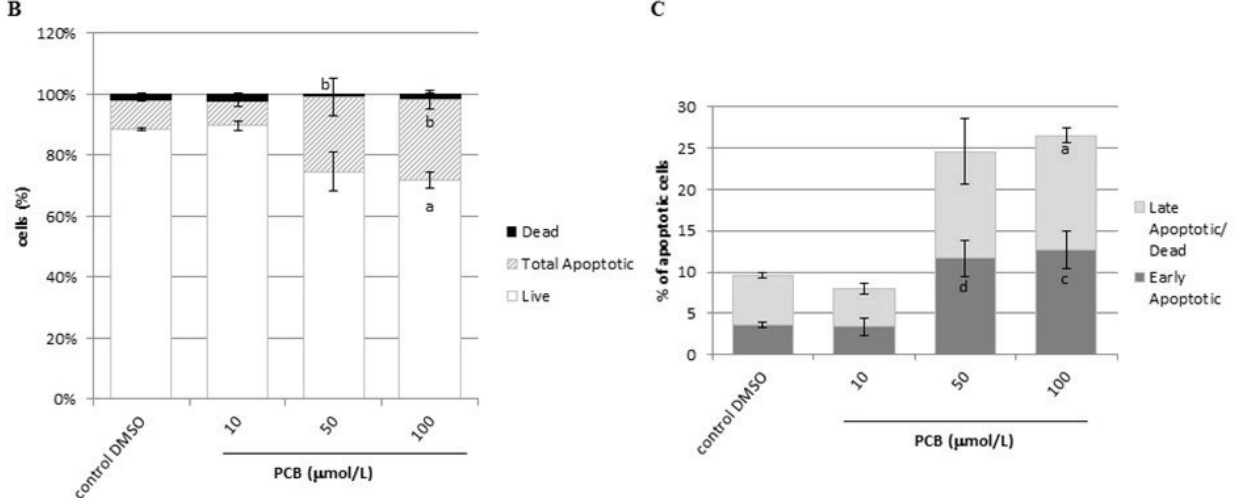

Figure 2 CHO-K1 cell death after $6 \mathrm{~h}$ of exposure to 10-100 $\mu \mathrm{mol} / \mathrm{L}$ PCB 153. (A) representative dot plot profiles of control and PCB-treated cells; (B) distribution of live, total apoptotic, and dead cells (mean \pm SEM); (C) distribution of early apoptotic and late apoptotic/dead cells relative to the total number of cells (mean \pm SEM). Statistical significance $v s$ respective controls: ${ }^{a} \mathrm{p}<0.001 ;{ }^{b} \mathrm{p}<0.005$; ${ }^{\mathrm{c}} \mathrm{p}<0.01 ;{ }^{\mathrm{d}} \mathrm{p}<0.025$

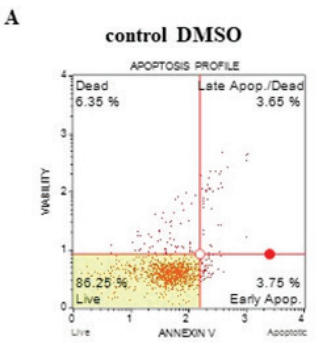

B
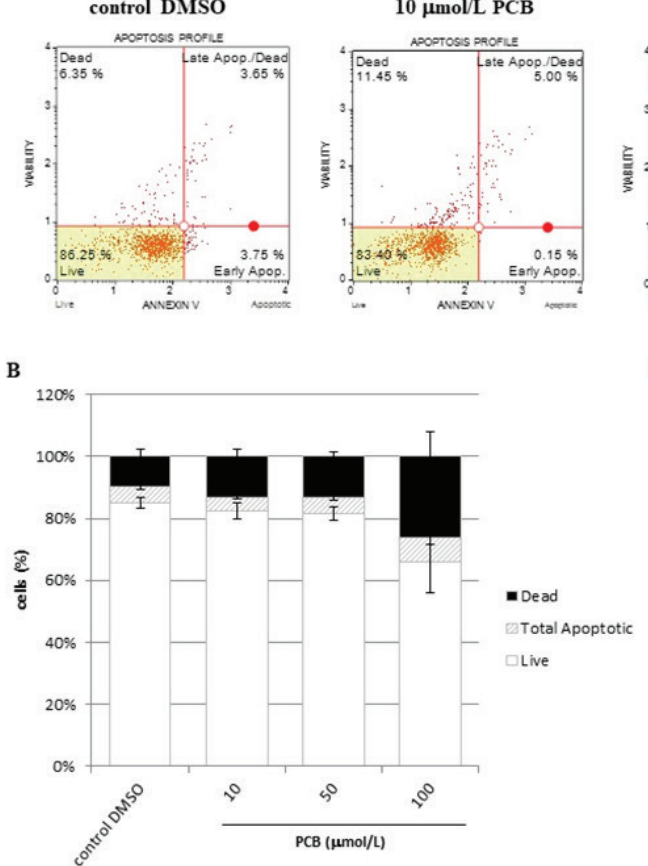

$50 \mu \mathrm{mol} / \mathrm{L}$ PCB
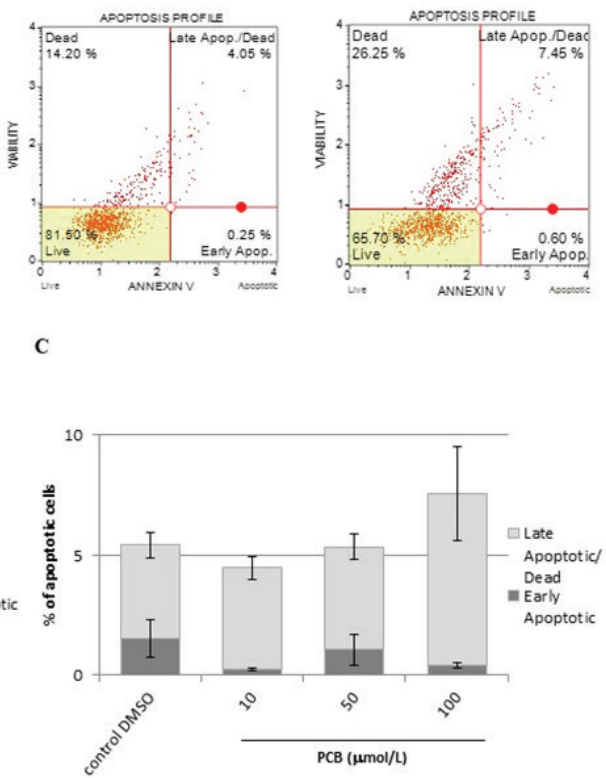

Figure $3 \mathrm{CHO}-\mathrm{K} 1$ cell death after $48 \mathrm{~h}$ of exposure to 10-100 $\mu \mathrm{mol} / \mathrm{L}$ PCB 153. (A) representative dot plot profiles of control and PCB-treated cells; (B) distribution of live, total apoptotic, and dead cells (mean \pm SEM); (C) distribution of early apoptotic and late apoptotic/dead cells relative to the total number of cells (mean \pm SEM) 
Table 1 Inhibition concentrations ( $\mu \mathrm{mol} / \mathrm{L}$ ) determined with four different cytotoxicity assays after 6, 24, 48, and $72 \mathrm{~h}$ of CHO-K1 cell exposure to PCB 153

\begin{tabular}{|c|c|c|c|c|c|c|c|c|c|c|c|c|}
\hline \multicolumn{13}{|c|}{ PCB $153(\mu \mathrm{mol} / \mathrm{L})$} \\
\hline \multirow[b]{2}{*}{ Endpoint } & \multicolumn{3}{|c|}{$6 \mathrm{~h}$} & \multicolumn{3}{|c|}{$24 \mathrm{~h}$} & \multicolumn{3}{|c|}{$48 \mathrm{~h}$} & \multicolumn{3}{|c|}{$72 \mathrm{~h}$} \\
\hline & IC $_{20}$ & $\mathrm{IC}_{50}$ & $\mathrm{IC}_{80}$ & $\mathrm{IC}_{20}$ & $\mathrm{IC}_{50}$ & $\mathrm{IC}_{80}$ & $\mathrm{IC}_{20}$ & $\mathrm{IC}_{50}$ & $\mathrm{IC}_{80}$ & $\mathrm{IC}_{20}$ & $\mathrm{IC}_{50}$ & $\mathrm{IC}_{80}$ \\
\hline TB & 32.7 & 66.3 & 92.6 & 23.3 & 64.5 & ND & 28.5 & 66.1 & 98.3 & 20.8 & 55.5 & 88.6 \\
\hline NR & 61.5 & ND & ND & 22.6 & 65.9 & ND & 34.0 & 65.2 & 89.3 & 21.7 & 51.0 & 78.3 \\
\hline KB & 61.0 & ND & ND & 77.4 & ND & ND & 73.0 & 95.9 & ND & 85.2 & ND & ND \\
\hline MTT & 19.7 & 58.4 & 98.6 & 67.8 & ND & ND & 63.4 & ND & ND & 34.8 & 86.7 & ND \\
\hline
\end{tabular}

All presented values were determined with polynomial interpolation from dose-response curves. TB - Trypan Blue; NR - Neutral Red; KB - Kenacid Blue; ND - not determined

regarding antiproliferative effects are scarce. An exception is the study by Oenga et. al. (26), who showed effective inhibition of E2-stimulated breast cancer cell proliferation by PCBs (in the following order: PCB $81>$ PCB 126= PCB 169>PCB 77).

\section{Effects of PCB 153 on cell cycle progression in $\mathrm{CHO}-\mathrm{K} 1$} cells

Figure 4 shows representative DNA histograms (A) and the distribution of cells across the G0 (sub G1), G0/G1, S, and $\mathrm{G} 2 / \mathrm{M}$ phases of the cell cycle (average of two experiments) (B). Treatment with $50 \mu \mathrm{mol} / \mathrm{L}$ PCB 153 disturbed the normal cell cycle progression in a timedependent manner, and the most significant changes were observed at $72 \mathrm{~h}$ of exposure. Time dependency was also evident in the increase in the apoptotic peak at $48 \mathrm{~h}$ (Figure 4A). We reported similar findings for PCB 77 earlier (13) and Venkatesha et al. (5) also reported that PCB 153 inhibited the entry of MCF-10A human mammary epithelial cells into the S-phase, while the proportion of G1 cells remained high (90-95\%).

\section{Effects of PCB 153 on ROS formation}

PCB 153 showed dose-dependent induction of oxidative stress in CHO-K1 cells (Figure 5), except for the lowest tested dose. Our findings are in line with numerous findings that apoptosis induced by PCBs is mediated in part by elevated levels of ROS (27-30).

\section{CONCLUSION}

We confirmed the hypothesis that intracellular effects of $\mathrm{PCB}$ congeners vary by their structure and planarity. $\mathrm{IC}_{50}$

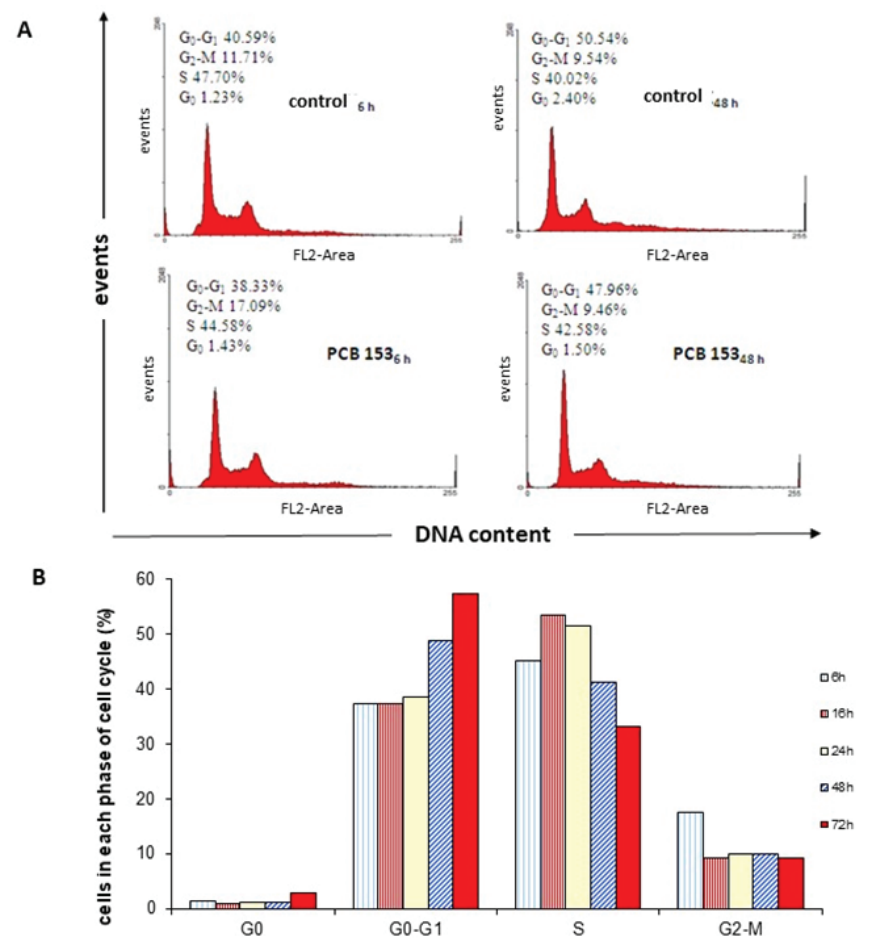

Figure 4 CHO-K1 cell cycle analysis after exposure to $50 \mu \mathrm{mol} / \mathrm{L}$ PCB 153 . (A) representative flow cytometric histograms of cell cycle progression after 6 and 48-hour exposure (B) Distribution (percentage) of exposed cells across the cell cycle phases over $72 \mathrm{~h}$ 


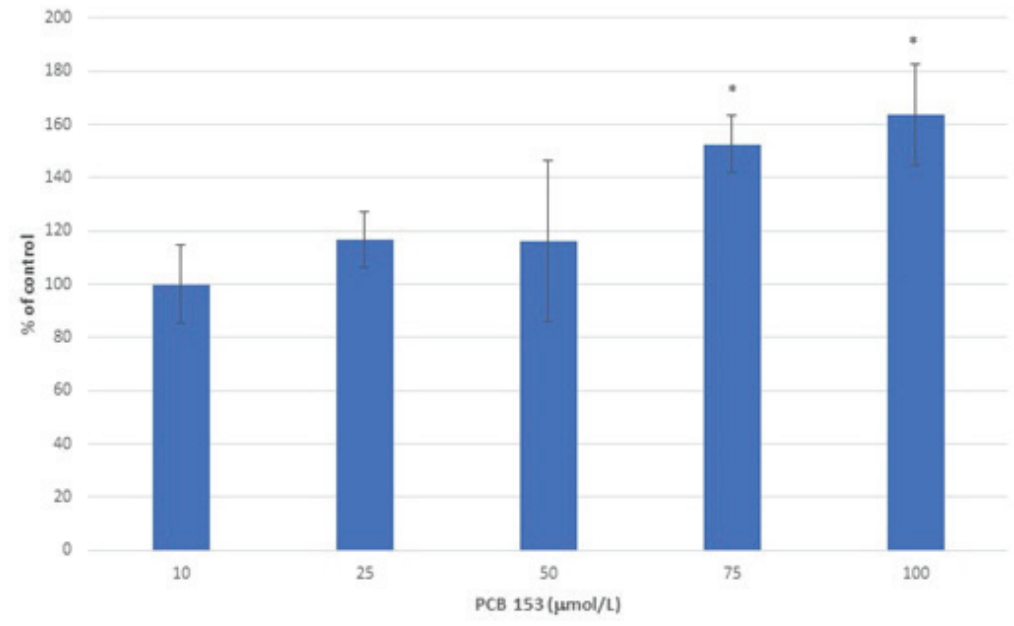

Figure 5 Effects of 10-100 $\mu \mathrm{mol} / \mathrm{L}$ PCB 153 on ROS formation in CHO-K1 cells. Data are presented as mean percentage of control $( \pm$ SEM). " $p<0.05$ vs control

values for PCB 153 were higher than those previously determined for PCB 77 (13), which correlates with their $\mathrm{LD}_{50}$ values in vivo (31). Cells respond rapidly to orthosubstituted PCB 153 by altering morphology, growth, mitochondrial metabolic rate, oxidative status, and biochemical processes that control cell death. Short incubation with PCB 153 induced apoptosis, whereas prolonged incubation initiated necrosis. Impaired oxidative status and dysregulation of cell death can result in severe pathological syndromes. Future research should further elucidate the connection between disturbed intracellular processes and clinical manifestations of PCB toxicity.

\section{Conflict of interests}

None to declare.

\section{Acknowledgments}

This study was supported by the Croatian Ministry of Science, Education, and Sports (grant No. 058-05821842232 and 00007000 2226).

\section{REFERENCES}

1. Phillips MC, Dheer R, Santaolalla R, Davies JM, Burgueño J, Lang JK, Toborek M, Abreu MT. Intestinal exposure to PCB 153 induces inflammation via the ATM/NEMO pathway. Toxicol Appl Pharmacol 2018;339:24-33. doi: 10.1016/j. taap.2017.11.027

2. Albaigés J, Murciano C, Pon J. Hazardous substances in the Mediterranean: a spatial and temporal assessment. Action Plan, Athens; 2011 [displayed 28 April 2020]. Available at http://195.97.36.231/dbases/MAPmeetingDocs/11WG365 Inf4_Eng.pdf
3. Kmetič I, Murati T, Kvakan K, Ivanjko M, Šimić B. Polychlorinated biphenyls - toxicity and risks. Croat J Food Sci Technol 2012;4:71-80.

4. Undeman E, Brown TN, McLachlan MS, Wania F. Who in the world is most exposed to polychlorinated biphenyls? Using models to identify highly exposed populations. Environ Res Lett 2018;13:064036. doi: 10.1088/1748-9326/aac5fe

5. Venkatesha VA, Kalen AL, Sarsour EH, Goswami PC. PCB153 exposure coordinates cell cycle progression and cellular metabolism in human mammary epithelial cells. Toxicol Lett 2010;196:110-6. doi: 10.1016/j.toxlet.2010.04.005

6. Orloff KG, Deartwent S, Metcalf S, Kathman S, Turner W. Human exposure to polychlorinated biphenyls in residential community. Arch Environ Contam Toxicol 2003;44:125-31. doi: $10.1007 / \mathrm{s} 00244-002-1301-5$

7. International Agency for Research on Cancer (IARC). Polychlorinated Biphenyls and Polybrominated Biphenyls. IARC Monographs on the Evaluation of Carcinogenic Risks to Humans, vol. 107, 2016 [displayed 21 April 2020]. Available at https://monographs.iarc.fr/wp-content/uploads/2018/08/ mono107.pdf

8. Herceg Romanić S, Kljaković-Gašpić Z, Klinčić D, Ujević I. Distribution of persistent organic pollutants (POPs) in cultured mussels from the Croatian coast of the Adriatic Sea. Chemosphere 2014;114:69-75. doi: 10.1016/j. chemosphere.2014.04.017

9. Herceg Romanić S, Marenjak TS, Klinčić D, Janicki Z, Srebočan E, Konjević D. Organochlorine compounds in red deer (Cervus elaphus L.) and fallow deer (Dama dama L.) from inland and coastal Croatia. Environ Monit Assess 2012;184:5173-80. doi: 10.1007/s10661-011-2331-0

10. Herceg Romanić S, Krauthacker B. Organochlorine pesticides and PCB congeners in human milk from two population groups in Croatia. Bull Environ Contam Toxicol 2006;76:705-11. doi: 10.1007/s00128-006-0977-z

11. Klinčić D, Herceg Romanić $S$, Brčić Karačonji I, Matek Sarić M, Grzunov Letinić J, Brajenović N. Organochlorine pesticides and $\mathrm{PCBs}$ (including dl-PCBs) in human milk samples collected from multiparae from Croatia and comparison with 
primiparae. Environ Toxicol Phar 2016;45:74-9. doi: 10.1016/j.etap.2016.05.002

12. Choi W, Eum SY, Lee YW, Hennig B, Robertson LW, Toborek M. PCB 104-induced proinflammatory reactions in human vascular endothelial cells: relationship to cancer metastasis and atherogenesis. Toxicol Sci 2003; 47-56. doi: 10.1093/ toxsci $/ \operatorname{kfg} 149$

13. Murati T, Šimić B, Brozovic A, Kniewald J, Miletić Gospić A, Bilandžić N, Kmetič I. PCB 77 action in ovary cells cytotoxicity, apoptosis induction and cell cycle analysis. Toxicol Mech Methods 2015;25:302-11. doi: 10.3109/15376516.2015.1028605

14. Murati T, Miletić M, Pleadin J, Šimić B, Kmetič I. Cell membrane-related toxic responses and disruption of intercellular communication in PCB mechanisms of toxicity: A review. J Appl Toxicol 2020;40:1592-601. doi: 10.1002/ jat.4019

15. Sechman A, Batoryna M, Antos PA, Hrabia A. Effects of PCB 126 and PCB 153 on secretion of steroid hormones and mRNA expression of steroidogenic genes (STAR, HSD3B, CYP19A1) and estrogen receptors $(\mathrm{ER} \alpha, \mathrm{ER} \beta)$ in prehierarchical chicken ovarian follicles. Toxicol Lett 2016;264:29-37. doi: 10.1016/j. toxlet.2016.11.001

16. Wojtowicz A, Ropstad E, Gregoraszczuk E. Estrous cycle dependent changes in steroid secretion by pig ovarian cells in vitro to polychlorinated biphenyl (PCB 153). Endocr Regul 2001;35:223-8. PMID: 11858770

17. Gregoraszczuk EL, Sowa M, Kajta M, Ptak A, Wójtowicz A. Effect of PCB 126 and PCB 153 on incidence of apoptosis in cultured theca and granulosa cells collected from small, medium and large preovulatory follicles. Reprod Toxicol 2003;17:465-71. doi: 10.1016/S0890-6238(03)00042-X

18. Bonefeld-Jørgensen EC, Raun Andersen H, Høj Rasmussen T, Vinggaard AM. Effect of highly bioaccumulated polychlorinated biphenyl congeners on estrogen and androgen receptor activity. Toxicology 2001;158:141-53. doi: 10.1016/ S0300-483X(00)00368-1

19. Fernández Freire P, Peropadre A, Pérez Martín JM, Herrero O, Hazen MJ. An integrated cellular model to evaluate cytotoxic effects in mammalian cell lines. Toxicol in Vitro 2009;23:1553-8. doi: 10.1016/j.tiv.2009.06.017

20. Kmetič I, Gaurina Srček V, Slivac I, Šimić B, Kniewald Z, Kniewald J. Atrazine exposure decreases cell proliferation in Chinese Hamster Ovary (CHO-K1) cell line. Bull Environ Contam Toxicol 2008;81:205-9. doi: 10.1007/s00128-0089425-6

21. Cocco S, Secondo A, Del Viscovo A, Procaccini C, Formisano L, Franco C, Esposito A, Scorziello A, Matarese G, Di Renzo
G, Canzoniero LMT. Polychlorinated biphenyls induce mitochondrial dysfunction in SH-SY5Y neuroblastoma cells. PLoS One 2015;10:e0129481. doi: 10.1371/journal. pone. 0129481

22. Gao M, Wu N, Song Y, Jin L, Lou J, Tao H. PCB153-induced oxidative stress and cell apoptosis on cultured rat Sertoli cells. Toxicol Res 2013;2:173-9. doi: 10.1039/c2tx20043k

23. Sánchez-Alonso JA, López-Aparicio P, Recio MN, PérezAlbarsanz MA. Apoptosis-mediated neurotoxic potential of a planar (PCB 77) and a nonplanar (PCB 153) polychlorinated biphenyl congeners in neuronal cell cultures. Toxicol Lett 2003;144:337-49. doi: 10.1016/S0378-4274(03)00238-8

24. Antos PA, Hrabia A, Gdula A, Sechman A. Apoptosis in chicken ovarian follicles following in vitro exposure to TCDD, PCB 126 and PCB 153. Ann Anim Sci 2017;17:787-98. doi: 10.1515/aoas-2016-0087

25. Jeon YJ, Youk ES, Lee SH, Suh J, Na YJ, Kim HM. Polychlorinated biphenyl-induced apoptosis of murine spleen cells is aryl hydrocarbon receptor independent but caspases dependent. Toxicol Appl Pharmacol 2002;181:69-78. doi: 10.1006/taap.2002.9389

26. Oenga GN, Spink DC, Carpenter DO. TCDD and PCBs inhibit breast cancer cell proliferation in vitro. Toxicol in Vitro 2004;18:811-9. doi: 10.1016/j.tiv.2004.04.004

27. Ghosh S, De S, Chen Y, Sutton DC, Ayorinde FO, Dutta SK. Polychlorinated biphenyls (PCB-153) and (PCB-77) absorption in human liver (HepG2) and kidney (HK2) cells in vitro: PCB levels and cell death. Environ Int 2010;36:893-900. doi: 10.1016/j.envint.2010.06.010

28. Yang D, Lein PJ. Polychlorinated biphenyls increase apoptosis in the developing rat brain. Curr Neurobiol 2010;1:70-6. PMID: 24052688

29. Ferrante MC, Mattace Raso G, Esposito E, Bianco G, Iacono A, Clausi MT, Amero P, Santoro A, Simeoli R, Autore G, Meli R. Effects of non-dioxin-like polychlorinated biphenyl congeners (PCB 101, PCB 153 and PCB 180) alone or mixed on J774A.1 macrophage cell line: modification of apoptotic pathway. Toxicol Lett 2011;202:61-8. doi: 10.1016/j. toxlet.2011.01.023

30. Murati T, Šimić B, Pleadin J, Vukmirović M, Miletić M, Durgo K, Kniewald J, Kmetič I. Reduced cytotoxicity in PCBexposed Chinese Hamster Ovary (CHO) cells pretreated with vitamin E. Food Chem Toxicol 2017;99:17-23. doi: 10.1016/j. fct.2016.11.014

31. NIH National Center for Biotechnology Information. PubChem [displayed 16 November 2021]. Available at https:// pubchem.ncbi.nlm.nih.gov/

\section{Ortho-supstituirani PCB 153 - unutarstanični učinci u CHO-K1 staničnoj liniji}

Neplanarni di-ortho-supstituirani PCB 153 (2,2',4,4',5,5'-heksaklorobifenil) jedan je od najčešćih PCB kongenera detektiranih u biološkim i u uzorcima iz okoliša. Identificiran je kao potencijalni endokrini modulator koji uzrokuje štetne učinke na reproduktivnom i endokrinom sustavu glodavaca, divljih životinja i ljudi. Ovo istraživanje pruža uvid u mehanizme djelovanja PCB 153 na stanicama ovarija. Primjenom četiriju metoda (Trypan Blue, Neutral Red, Kenacid Blue i MTT) utvrđeno je da PCB $153(10-100 \mu \mathrm{mol} / \mathrm{L})$ reducira proliferaciju CHO-K1 stanica, a od primijenjenih se metoda MTT test pokazao kao najosjetljiviji. PCB 153 inducirao je stvaranje ROS-a u stanicama ovarija, ovisno o primijenjenoj dozi. Citofluorimetrijska analiza upozorava na indukciju apoptoze nakon šest sati izloženosti stanica PCB-u 153 u dozama $\geq 50 \mu \mathrm{mol} / \mathrm{L}$, a produljena izloženost rezultirala je aktivacijom nekroze. PCB 153 uzrokovao je poremećaje u progresiji staničnog ciklusa, s najznačajnijim promjenama uočenima nakon 72 sata izloženosti.

KLJUČNE RIJEČI: citotoksičnost; poliklorirani bifenili; ROS; stanična smrt; stanični ciklus 